\title{
Treatment of Dystonia
}

\author{
Mary Ann Thenganatt • Joseph Jankovic
}

Published online: 19 October 2013

(C) The American Society for Experimental NeuroTherapeutics, Inc. 2013

\begin{abstract}
Selecting the appropriate treatment for dystonia begins with proper classification of disease based on age, distribution, and underlying etiology. The therapies available for dystonia include oral medications, botulinum toxin, and surgical procedures. Oral medications are generally reserved for generalized and segmental dystonia. Botulinum toxin revolutionized the treatment of focal dystonia when it was introduced for therapeutic purposes in the 1980s. Surgical procedures are available for medication-refractory dystonia, markedly affecting an individual's quality of life.
\end{abstract}

Key Words Dystonia $\cdot$ cervical dystonia $\cdot$ blepharospasm . trihexyphenidyl · botulinum toxin $\cdot$ deep brain stimulation

\section{Introduction}

Since its first descriptions in the 1890s and the introduction of the term "dystonia" by Oppenheim in 1911, there has been remarkable progress in understanding this disorder leading to a concise definition, coherent classification, and the development of beneficial symptomatic treatments. Dystonia is now defined as a movement disorder characterized by sustained or intermittent muscle contractions often causing abnormal, repetitive, patterned, and twisting movements [1]. With the observation that young-onset dystonia appeared to be hereditary, coupled with advances in genetic techniques, several genes associated with dystonia have been identified (Table 1) [2]. Underlying mechanisms of disease that have been

Electronic supplementary material The online version of this article (doi:10.1007/s13311-013-0231-4) contains supplementary material, which is available to authorized users.

M. A. Thenganatt $\cdot$ J. Jankovic $(\bowtie)$

Parkinson's Disease Center \& Movement Disorders Clinic,

Department of Neurology, Baylor College of Medicine, 6550 Fannin,

Suite 1801, Houston, TX 77030, USA

e-mail: josephj@bcm.edu suggested include loss of cortical inhibition, increased cortical and subcortical neuroplasticity, and abnormal sensory processing with impaired spatial and temporal discrimination [3-5]. Despite a greater understanding of the disease process, treatment for dystonia remains symptomatic, rather than targeted at underlying pathophysiology. Included in the armamentarium to treat dystonia are oral medications, botulinum toxin and surgical procedures, predominantly deep brain stimulation (DBS). When selecting therapy for dystonia it is important to take into consideration age, distribution of disease, underlying etiology, goals of treatment, and influence of the dystonia on activities of daily living and quality of life [6]. In this review we discuss the various treatment options for dystonia, including oral medications, botulinum toxin, surgical procedures, physical, and other modes of therapy (Table 2).

\section{Oral medications}

Oral medications are recommended predominantly for segmental and generalized dystonia. We recommend initial treatment with botulinum toxin for focal dystonia because it is highly effective, with less potential for systemic side effects than oral medications. Oral medications may be used in focal dystonia as an add-on therapy to botulinum toxin to obtain more symptomatic relief. Oral medications are often limited by systemic side effects; however, children may be able to tolerate high doses of medications with good benefit. Medications should be initiated at a low dose and slowly up-titrated over weeks to minimize adverse effects. Often, a combination of medications may be required.

\section{Trihexyphenidyl}

Trihexyphenidyl, an anticholinergic, is the only oral medication studied in a double-blind fashion for dystonia. One early 
Table 1 DYT loci with associated gene, protein and function (if known). DYT9 (identical to DYT18), DYT14 (identical to DYT5a), and DYT19 (identical to DYT10) are omitted

\begin{tabular}{|c|c|c|c|}
\hline Designation & Gene & Protein & Proposed protein function \\
\hline DYT1 & TORIA & Torsin $\mathrm{A}$ & $\begin{array}{l}\text { AAA + family of ATPases, protein } \\
\text { processing, and trafficking }\end{array}$ \\
\hline DYT2 & Unknown & & \\
\hline DYT3 & $T A F 1$ & $\begin{array}{l}\text { TAF1 RNA polymerase II, } \\
\text { TATA box-binding } \\
\text { protein-associated factor }\end{array}$ & Regulation of transcription \\
\hline DYT4 & TUBB4 & TUBB4 & Tubulin, major component of cytoskeleton \\
\hline DYT5 & $\begin{array}{l}\text { a) } \\
\text { GTPCH1 } \\
\text { b) } \\
\text { SR } \\
\text { TH }\end{array}$ & & $\begin{array}{l}\text { Enzymes involved in catecholamine } \\
\text { synthesis }\end{array}$ \\
\hline DYT6 & THAP1 & THAP1 & Zinc finger transcription factor \\
\hline DYT7 & Unknown & & \\
\hline DYT8 & PNKD1/MR-1 & PNKD protein/MR-1 protein & Unknown \\
\hline DYT10 & PRRT2 & PRRT2 protein & $\begin{array}{l}\text { Possibly involved in neurotransmitter } \\
\text { release }\end{array}$ \\
\hline DYT11 & $S G C E$ & Epsilon-sarcoglycan & Dystrophin-glycoprotein complexes \\
\hline DYT12 & ATP1A3 & $\mathrm{Na}^{+} / \mathrm{K}^{+}$ATPase $\alpha$-subunit & Ion transport \\
\hline DYT13 & Unknown & & \\
\hline DYT15 & Unknown & & \\
\hline DYT16 & PRKRA & & Stress response protein \\
\hline DYT17 & Unknown & & \\
\hline DYT18 & $S L C 2 A 1(G L U T 1)$ & GLUT1 & Glucose transporter \\
\hline DYT20 & Unknown & & \\
\hline DYT21 & Unknown & & \\
\hline DYT23 & CIZ1 & $\begin{array}{l}\text { CDKN1A interacting zinc } \\
\text { finger protein }\end{array}$ & DNA synthesis and cell cycle control \\
\hline DYT24 & $A N O 3$ & Anoctamin 3 & Calcium-gated chloride channel \\
\hline DYT25 & $G N A L$ & $\mathrm{G} \alpha_{\text {olf }}$ & $\begin{array}{l}\text { G protein; dopamine, D1, signaling; } \\
\text { adenosine A2A receptors }\end{array}$ \\
\hline
\end{tabular}

trial involving 31 patients, aged 32 years or younger, with dystonia demonstrated the tolerability of a 30-mg dose of trihexyphenidyl and sustained significant benefit at a mean follow-up of 2.4 years in $42 \%$ of patients [7]. Trihexyphenidyl should be started at half a 2-mg tablet and slowly increased by half tablets until optimal benefit or side effects are encountered. Potential anticholinergic side effects include dry mouth, blurred vision, constipation, urinary retention, and cognitive changes. Side effects, particularly cognitive impairment, such as memory loss and delayed processing are more likely to occur in older patients [8]. An absolute contraindication to the use of trihexyphenidyl is acute closedangle glaucoma, but the drug should be used cautiously in patients with any cognitive impairment, constipation, and symptoms of prostatism. Anticholinergic side effects may be counteracted by other medications, such as artificial saliva for dry mouth, pyridostigmine for constipation and urinary retention, and pilocarpine eye drops for blurred vision.

\section{Baclofen}

Baclofen is a pre-synaptic gamma aminobutryic acid agonist found to be efficacious in the treatment of dystonia in retrospective studies [9]. It can be particularly effective in children with dystonic gait, as well as other forms of segmental dystonia [9]. Average daily doses of baclofen range from 60 to $120 \mathrm{mg}$. Baclofen may be used as adjunct therapy with trihexyphenidyl for additional benefit. Based on observation, elderly patients tend to tolerate baclofen better than trihexyphenidyl. Potential side effects of baclofen include sedation, dizziness, and hypotonia. Thus, caution should be taken in 
Table 2 Treatment options for dystonia

\begin{tabular}{|c|c|}
\hline Medication & Mechanism of action \\
\hline \multicolumn{2}{|l|}{ 2a) Oral medications } \\
\hline Trihexyphenidyl & Anticholinergic \\
\hline Baclofen & GABA-B receptor agonist \\
\hline $\begin{array}{l}\text { Benzodiazepines } \\
\text { Lorazepam }\end{array}$ & GABA enhancer \\
\hline \multicolumn{2}{|l|}{ Diazepam } \\
\hline \multicolumn{2}{|l|}{ Clonazepam } \\
\hline Carbidopa-levodopa & Metabolic precursor of dopamine \\
\hline \multicolumn{2}{|l|}{ Muscle relaxants } \\
\hline $\begin{array}{l}\text { Cycloben- } \\
\text { zaprine }\end{array}$ & Skeletal muscle relaxant \\
\hline Metaxalone & Skeletal muscle relaxant \\
\hline Carisoprodol & Skeletal muscle relaxant \\
\hline $\begin{array}{l}\text { Methocar- } \\
\text { bamol }\end{array}$ & Skeletal muscle relaxant \\
\hline Orphenadrine & Skeletal muscle relaxant \\
\hline $\begin{array}{l}\text { Chlorzoxa- } \\
\text { zone }\end{array}$ & Skeletal muscle relaxant \\
\hline Sodium oxybate & Salt of gamma-hydroxybutyric acid \\
\hline Tetrabenazine & $\begin{array}{l}\text { Vesicular monoamine transporter } 2 \text { inhibitor } \\
\text { Weak D2 receptor antagonist }\end{array}$ \\
\hline Clozapine & Dopamine receptor antagonist, mainly D4 \\
\hline Carbamazepine & Anticonvulsant, sodium channel inhibitor \\
\hline Oxcarbazepine & Anticonvulsant, sodium channel inhibitor \\
\hline Zolpidem & $\begin{array}{l}\text { Non-benzodiazepine hypnotic, affinity for } \\
\text { GABA-benzodiazepine subtype receptor } \\
\text { BZ1 }(\omega 1)\end{array}$ \\
\hline Pregabalin & Calcium channel inhibitor \\
\hline \multicolumn{2}{|c|}{ 2b) Non-pharmacologic therapies } \\
\hline \multicolumn{2}{|c|}{ Botulinum toxin } \\
\hline \multicolumn{2}{|c|}{ OnabotulinumtoxinA } \\
\hline \multicolumn{2}{|c|}{ AbobotulinumtoxinA } \\
\hline \multicolumn{2}{|c|}{ IncobotulinumtoxinA } \\
\hline \multicolumn{2}{|c|}{ RimabotulinumtoxinB } \\
\hline \multicolumn{2}{|l|}{ Surgery } \\
\hline \multicolumn{2}{|c|}{ Deep brain stimulation } \\
\hline \multicolumn{2}{|c|}{ Ablative procedures } \\
\hline \multicolumn{2}{|c|}{ Selective peripheral denervation } \\
\hline \multicolumn{2}{|c|}{ Intrathecal baclofen } \\
\hline \multicolumn{2}{|c|}{ Intraventricular baclofen } \\
\hline \multicolumn{2}{|c|}{ Oculofacial plastic procedures } \\
\hline \multicolumn{2}{|c|}{ Other therapies } \\
\hline \multicolumn{2}{|l|}{ Physical therapy } \\
\hline \multicolumn{2}{|l|}{ Braces } \\
\hline \multicolumn{2}{|l|}{ Eyelid crutches } \\
\hline \multicolumn{2}{|c|}{ Dental devices } \\
\hline \multicolumn{2}{|c|}{ Transcranial magnetic stimulation } \\
\hline Transcranial altern & rrent stimulation \\
\hline
\end{tabular}

$\mathrm{GABA}=$ gamma aminobutyric acid patients with underlying weakness in addition to dystonia, as these patients may need some increased tone to ambulate. Note should be made of withdrawal seizures with abrupt discontinuation of baclofen; thus, a gradual taper is recommended.

\section{Dopamine Antagonists and Dopamine-depleting Drugs}

While D2 receptor blocking agents or neuroleptics have been prescribed for the treatment of dystonia, the use of these agents is discouraged because of the risk of the potentially permanent side effect of tardive dyskinesia. One exception is the use of the atypical neuroleptic clozapine, which was demonstrated to be effective for dystonia in a small open trial involving only 5 patients [10]. Improvement was seen in subjective responses and clinical rating scale in all 5 patients. There have also been case reports of sustained improvement with clozapine for the treatment of tardive axial dystonia [11]. Perhaps because of its greater affinity for D4 receptors as opposed to D2 receptors, clozapine is much less likely to cause tardive dyskinesia than other dopamine receptorblocking agents. Nonetheless, there have been reports of tardive dystonia caused by clozapine as well; thus, this should be a drug of last resort. Use of this drug may be limited by side effects of orthostatic hypotension, sedation, and agranulocytosis requiring regular blood work.

Tetrabenazine is a dopamine-depleting agent that inhibits vesicular monoamine transporter type 2 in the central nervous system, depleting dopamine, norepinephrine, and serotonin. It was approved by the US Federal Drug Administration (FDA) in 2008 for the treatment of Huntington's chorea, but has been shown to be effective for other hyperkinetic movement disorders, including dystonia, in retrospective studies [12]. While tetrabenazine has mild D2 receptor-blocking activity, there have been no confirmed reports of tardive dyskinesia with this agent. One retrospective chart review at Baylor College of Medicine evaluated the tolerability of tetrabenazine for the treatment of 448 patients with various hyperkinetic movement disorders, including 132 patients with dystonia [12]. For the entire cohort, the daily dose of tetrabenazine was $50-75 \mathrm{mg}$ per day. At the last visit, $69.5 \%$ of dystonia patients had an excellent or moderate improvement in symptoms. Although patients with idiopathic dystonia may benefit from tetrabenazine, the best candidates for this treatment are patients with tardive dystonia. Tetrabenazine can be started at $12.5 \mathrm{mg}$ daily, increasing by $12.5 \mathrm{mg}$ until optimal benefit or side effects are reached. Side effects include drowsiness, insomnia, akathisia, parkinsonism, and depression [13, 14]. Adverse effects are dose-related and reversible upon lowering the medication. Parkinsonism can be treated with amantadine, dopamine agonists, or levodopa; depression with 
antidepressants; and insomnia and akathisia with zolpidem [15], which may also help dystonia [16]. Such a strategy may allow the patient to continue the tetrabenazine treatment, particularly if it benefits the underlying dystonia.

Reserpine, a dopamine-depleting agent, has also been found to be effective for tardive dystonia in retrospective studies [17]. Reserpine is an irreversible inhibitor of vesicular monoamine transporter type 1 in the peripheral nervous system, as well as vesicular monoamine transporter type 2 in the central nervous system. Side effects of reserpine include parkinsonism and depression, as well as peripheral side effects of light-headedness and gastrointestinal upset. Thus, tetrabenazine is often preferred over reserpine to avoid these additional peripheral side effects.

\section{Levodopa}

Levodopa is extremely effective at low doses for the treatment of dopa-responsive dystonia (DRD). DRD, a disorder caused by a defect in dopamine synthesis, is classically exemplified by childhood-onset dystonia beginning in the legs and with diurnal variation manifested by worsening of symptoms as the day progresses. In approximately $50 \%$ of cases DRD is caused by an autosomal dominant gene defect in $\mathrm{GCH} 1$, which encodes for guanosine triphosphate cyclohydrolase 1 [18]. A study of 34 patients with DRD and GCH1 gene mutations described other manifestations of the disease, including upper limb dystonia; cranial dystonia, including blepharospasm, cervical dystonia, and spasmodic dysphonia; hyperreflexia; postural instability; and tremor. Patients have a dramatic response to low doses of levodopa (300 mg/day) with long-term benefit [19]. Some patients may need a higher dosage (600-1000 mg/day); thus, higher doses should be tried. One review of 34 patients with DRD found that all but 1 patient required doses $<600 \mathrm{mg} /$ day of levodopa (range, 25$1050 \mathrm{mg}$ ) [18]. Dyskinesias can occur at higher doses and resolve with a dose reduction [20]. Sepiapterin deficiency, an autosomal recessive variant of $\mathrm{DRD}$, also responds to levodopa with additional improvement with 5-hydroxytryptophan as adjunct therapy [21]. Other disorders of dopamine metabolism that can cause dystonia include tyrosine hydroxylase deficiency, aromatic amino acid decarboxylase deficiency, and 6pyruvol-tetrahydropterin synthase deficiency [22]. DRD is often mistaken for cerebral palsy; thus, treatment with levodopa should be considered in all children with dystonia. Additionally, there are case reports of other types of dystonia responding to levodopa and thus may also be helpful in the adult population $[23,24]$.

\section{Other Agents}

Various other agents have been reported to be effective for dystonia in case reports, case series, and small prospective trials. Ethopropazine has been used in the past as an anticholinergic agent, but there are no controlled trials to document its efficacy in dystonia. Muscle relaxants such as orphenadrine, cyclobenzaprine, metaxalone, carisoprodol, methocarbamol, and chlorzoxazone may help treat pain associated with muscle spasm. Benzodiazepines, such as clonazepam, diazepam, and lorazepam, may be used to treat various forms of dystonia, and is especially useful for myoclonus-dystonia [25]. Sodium oxybate was demonstrated to be efficacious in a pilot study for the treatment of alcohol-responsive disorders, such as myoclonus-dystonia [26]. In an open-label study involving 34 patients with dystonia, zolpidem, an agent with affinity for a benzodiazepine receptor, was found to be effective for generalized dystonia, cranial dystonia, blepharospasm, and hand dystonia, but not cervical dystonia [16]. Pregabalin was reported to be effective in a case of secondary dystonia after subarachnoid and intracerebral hemorrhage. Other anticonvulsants, such as oxcarbazepine and carbamazepine, can be used for the treatment of dystonia in patients with paroxysmal kinesigenic dyskinesia [27].

\section{Botulinum Toxin}

The introduction of botulinum toxin for therapeutic purposes in the 1980s revolutionized the treatment of focal dystonia. Botulinum toxin, produced by the bacterium Clostridium botulinum, occurs in seven immunologically distinct serotypes: A-G. The active portion of the toxin is a di-peptide comprised of a 100-kDa heavy chain and a 50-kDa light chain that prevents the release of acetylcholine at nerve terminals. The heavy chain binds to peripheral cholinergic nerve terminals to allow entry into the synaptic bulb, and the light chain cleaves soluble N-ethylmaleimide-sensitive factor attachment receptor proteins, which are required for the fusion of the presynaptic acetylcholine vesicle with the plasma membrane for the release of acetylcholine into the synaptic cleft. Botulinum toxin is isolated and purified, and there are 4 toxins commercially available in the USA: 3 type A and 1 type B (Table 3) [28]. In 1989, Botox (Allergan, Irvine, CA, USA) was approved by the FDA for the treatment of blepharospasm, hemifacial spasm, and strabismus. In 2000, Botox was approved for cervical dystonia. Since then, 3 other formulations have been approved by the FDA with various indications: Dysport (Ipsen, Slough, UK), Myobloc (US World Meds, Louisville, KY, USA) and Xeomin (Merz Pharmaceuticals, Greensboro, NC, USA). In 2009, nonproprietary names were assigned to the various commercially available toxins as follows: onabotulinumtoxinA (Botox), abobotulinumtoxin A (Dysport), incobotulinumtoxinA (Xeomin), and rimabotulinumtoxinB (Myobloc); only the latter is a type $\mathrm{B}$ toxin. 
Table 3 Formulations of botulinum toxin

\begin{tabular}{|c|c|c|c|c|c|c|c|c|}
\hline Trade name & Company & Nonproprietary name & Type & $\begin{array}{l}\text { SNARE } \\
\text { target }\end{array}$ & Preparation & $\begin{array}{l}\text { Storage } \\
\text { temperature }\end{array}$ & Units per vial & $\begin{array}{l}\text { US FDA approved } \\
\text { indications for dystonia } \\
\text { (year approved) }\end{array}$ \\
\hline Botox & Allergan, Irvine, CA, USA & OnabotulinumtoxinA & A & SNAP25 & Powder & $<8^{\circ} \mathrm{C}$ & $50,100,200$ & $\begin{array}{l}\text { Blepharospasm (1989); } \\
\text { cervical dystonia (2000) }\end{array}$ \\
\hline Dysport & Ipsen, Slough, UK & AbobotulinumtoxinA & A & SNAP25 & Powder & $<8^{\circ} \mathrm{C}$ & 300,500 & Cervical dystonia (2009) \\
\hline Xeomin & $\begin{array}{l}\text { Merz Pharmaceuticals, } \\
\text { Greensboro, NC, USA }\end{array}$ & Incobotulinumtoxin A & A & SNAP25 & Powder & $<25^{\circ} \mathrm{C}$ & 50,100 & $\begin{array}{l}\text { Blepharospasm; cervical } \\
\text { dystonia (2010) }\end{array}$ \\
\hline Myobloc & $\begin{array}{l}\text { US World Meds, Louisville, } \\
\text { KY, USA }\end{array}$ & RimabotulinumtoxinB & B & VAMP & Solution & $<8^{\circ} \mathrm{C}$ & $\begin{array}{l}2500,5000 \\
10,000\end{array}$ & Cervical dystonia (2000) \\
\hline
\end{tabular}

SNARE $=$ soluble N-ethylmaleimide-sensitive factor attachment receptor proteins; SNAP $=$ soluble N-ethylmaleimide sensitive fusion protein (NSF) attachment protein; VAMP $=$ vesicle-associated membrane protein; FDA $=$ Federal Drug Administration

The various formulations are not equivalent and one must be familiar with the properties and dosing of each toxin. Type A formulations are crystallized and dissolved in normal saline prior to use, while rimabotulinumtoxinB is already prepared in liquid form. All the above-mentioned formulations need to be stored in a cool environment, except for incobotulinumtoxinA, which is stable at room temperature. IncobotulinumtoxinA is free of accessory proteins and contains less inactive toxin, but evidence is still lacking whether it is less likely to cause neutralizing antibodies [29]. RimabotulinumtoxinB may have greater tendency for autonomic side effects such as dry mouth and constipation [30].

Botulinum toxin is an effective treatment for various forms of dystonia, including blepharospasm, cervical dystonia, oromandibular dystonia and bruxism, laryngeal dystonia, and focal limb dystonia, although with varying levels of evidence available for distinct disorders (Tables 4 and 5) [31-33]. Studies have confirmed the long-term efficacy and safety of botulinum toxin for dystonia [34, 35] (Tables 4 and 5). Potential side effects of botulinum toxin injections include local bruising, excess weakness, and flu-like symptoms. One study found the rate of flu-like reactions to be relatively low, occurring after $14 \%$ of visits; possibly related to increased levels of inducible protein 10 [36].

Potential challenges with botulinum toxin include primary and secondary resistance. Standardized measures of response to botulinum toxin are being developed to include magnitude and duration of improvement in posture and pain, and development of adverse events [37]. Primary nonresponsiveness may be owing to improper selection of muscles or inadequate dosage; rarely, patients previously immunized against botulism may have primary immunoresistance. One must be familiar with the muscles contributing to the abnormal movement and inject accordingly. There are limited studies supporting the use of electromyography to improve therapeutic response to botulinum toxin, and further studies are needed [38]. Inadequate response in cervical dystonia may also be owing to deep muscles not typically accessible with routine botulinum toxin injection procedures [39].
One potential concern with frequent or long-term use of botulinum toxin is the development of neutralizing antibodies and resistance. In 1998, a new batch of onabotulinumtoxinA was prepared with a lower protein load and there have been reports of decreased resistance [40]. As mentioned above, incobotulinumtoxinA is free of accessory proteins and contains less inactive toxin, with speculation that it is less likely to cause neutralizing antibodies, though evidence is lacking [29]. Assays to detect neutralizing antibodies are not readily available and not routinely used in clinical practice. Performing injection cycles no sooner than every 3 months may decrease the formation of neutralizing antibodies. When resistance to toxin is encountered, response may be restored by switching to the other serotype. Botulinum toxin is also a costly treatment, with limited studies evaluating its cost-benefit ratio [41]. Despite these challenges, botulinum toxin is an effective treatment for focal and segmental dystonia, and can markedly improve a patient's quality of life.

Oral zinc and phytase supplementation was reported to extend the duration of benefit of botulinum toxin for the treatment of blepharospasm in a double-blind, placebocontrolled, cross-over pilot study [42]. A topically-applied compound called Trans- $\mathrm{X}$, which is a fusion protein containing truncated soluble $\mathrm{N}$-ethylmaleimide sensitive fusion protein (NSF) attachment protein-25 (a soluble Nethylmaleimide-sensitive factor attachment receptor protein), has been shown in an experimental study to safely penetrate the skin and induce muscle paralysis based on measurements of compound muscle action potentials [43]. The authors suggest this as a potentially safer alternative to botulinum toxin.

\section{Surgical Treatments}

Surgical interventions are available for patients with medication and botulinum toxin-refractory dystonia significantly affecting their activities of daily living and quality of life. Ablative procedures, such as thalamotomy and pallidotomy, 
Table 4 Botulinum toxin: randomized, placebo-controlled trials

\begin{tabular}{|c|c|c|c|c|c|}
\hline Study [ref.] & Indication & $\mathrm{n}$ & Dose & Primary endpoint & Result \\
\hline \multicolumn{6}{|l|}{ OnabotulinumtoxinA (Ona) } \\
\hline $\begin{array}{l}\text { Jankovic and Orman, } \\
\text { 1987 [119] }\end{array}$ & Blepharospasm & 11 & 25 or 50 U/eye $v s$ placebo & $\begin{array}{l}\text { Fahn scale } \\
\text { Hyperkinesia Rating Scale } \\
\text { Self-assessment } \\
\text { Standardized video }\end{array}$ & $\begin{array}{l}76 \% \text { improvement on clinical scale, } p<0.01 \\
60.7 \% \text { improvement on self-assessment, } p<0.01 \\
38.9 \% \text { improvement on videotape, } p<0.04\end{array}$ \\
\hline Greene et al., 1990 [120] & Cervical dystonia & 55 & Varied active dose $v s$ placebo & $\begin{array}{l}\text { Columbia Torticollis Rating } \\
\text { Scale }\end{array}$ & $\begin{array}{l}\text { Significant improvement in all except one } \\
\text { subscore of rating scale }\end{array}$ \\
\hline $\begin{array}{l}\text { Jankovic and Orman, } \\
1987 \text { [119] }\end{array}$ & $\begin{array}{l}\text { Oromandibular } \\
\text { dystonia, } \\
\text { cervical } \\
\text { dystonia }\end{array}$ & 8 & Mean dose $52.8 \mathrm{U} v s$ placebo & $\begin{array}{l}\text { Fahn scale } \\
\text { Self-assessment } \\
\text { Standardized video }\end{array}$ & $\begin{array}{l}\text { Significant improvement in clinical and videotape } \\
\text { score, } p<0.01\end{array}$ \\
\hline $\begin{array}{l}\text { Yoshimura et al., } \\
1992[121]\end{array}$ & Limb dystonia & 17 & $13-120 \mathrm{U} v s$ placebo & $\begin{array}{l}\text { Subjective assessment } \\
\text { Video assessment }\end{array}$ & $\begin{array}{l}82 \% \text { had subjective improvement, } p<0.001 \\
\text { No significant improvement in objective } \\
\text { assessment compared with placebo }\end{array}$ \\
\hline Tsui et al., 1993 [122] & Limb dystonia & 11 & 25-30 U/muscle $v s$ placebo & Objective measures of writing & $\begin{array}{l}\text { Significant improvement in pen control, } p<0.05 \\
\text { Significant improvement in speed completion } \\
\text { of Gibson's maze, } p<0.05\end{array}$ \\
\hline \multirow[t]{2}{*}{ Cole et al., 1995 [123] } & Limb dystonia & 10 & 5-30 U vs placebo & $\begin{array}{l}\text { Subjective patient rating } \\
\text { Objective testing }\end{array}$ & $\begin{array}{l}8 \text { patients had subjective improvement } \\
6 \text { patients with an objective test that verified } \\
\text { the improvement }\end{array}$ \\
\hline & & & & Videotape assessment & \\
\hline \multirow[t]{2}{*}{ Troung et al., 1991 [124] } & $\begin{array}{l}\text { Laryngeal dystonia } \\
\quad \text { (adductor) }\end{array}$ & 13 & $\begin{array}{l}5 \mathrm{U} / \text { thyroarytenoid } \\
\text { muscle } v s \text { placebo }\end{array}$ & Objective assessments of speech & $\begin{array}{l}\text { Significant improvement in speech perturbation, } \\
\text { spectrographic analysis, and fundamental } \\
\text { frequency range }\end{array}$ \\
\hline & & & & Subjective assessment of speech & $\begin{array}{l}\text { Phonation time and fundamental frequency } \\
\text { unchanged. } \\
\text { Significant improvement in subjective assessment }\end{array}$ \\
\hline \multicolumn{6}{|l|}{ AbobotulinumtoxinA (Abo) } \\
\hline Truong et al., 2008 [125] & Blepharospasm & 120 & $\begin{array}{l}40,80,120 \mathrm{U} / \text { eye } \\
v s \text { placebo }\end{array}$ & $\begin{array}{l}\text { Percentage of normal activity } \\
\text { BDS at } 4 \text { weeks }\end{array}$ & $\begin{array}{l}\text { Percentage of normal activity of BDS significantly } \\
\text { better with Abo vs placebo with all doses, } \\
\text { p }<0.01\end{array}$ \\
\hline Poewe et al., 1998 [126] & Cervical dystonia & 75 & $\begin{array}{l}250,500 \text {, or } 1000 \mathrm{U} \\
\quad v s \text { placebo }\end{array}$ & $\begin{array}{l}\text { Modified Tsui scale at weeks } \\
2,4 \text {, and } 8\end{array}$ & $\begin{array}{l}\text { Significant reduction modified Tsui scale in } 500 \text { and } \\
1000 \mathrm{U} \text { groups at week } 4, p<0.05\end{array}$ \\
\hline Truong et al., 2005 [127] & Cervical dystonia & 80 & $500 \mathrm{U} v s$ placebo & TWSTRS at 4 weeks & $\begin{array}{l}\text { Greater mean reduction with Abo vs placebo (9.9 } \\
\quad \text { vs } 3.8, p \leq 0.013)\end{array}$ \\
\hline Truong et al., 2010 [128] & Cervical dystonia & 116 & $500 \mathrm{U} v s$ placebo & TWSTRS at 4 weeks & $\begin{array}{l}\text { Greater reduction with Abo vs placebo }(-15.6 \pm 2.0) \\
\quad \text { vs } 6.7 \pm 2.0), p<0.001\end{array}$ \\
\hline Lee et al., 2010 [129] & $\begin{array}{l}\text { Oromandibular } \\
\text { dystonia }\end{array}$ & 12 & $80 \mathrm{U} v s$ placebo & $\begin{array}{l}\text { Number of EMG-recorded } \\
\text { bruxism events at } 4,8, \\
\text { and } 12 \text { weeks }\end{array}$ & $\begin{array}{l}\text { Significantly decreased bruxism events in } \\
\text { the masseter at all time points }\end{array}$ \\
\hline Kruisdijk et al., 2007 [130] & Limb dystonia & 40 & $20 \mathrm{U} v s$ placebo & $\begin{array}{l}\text { Patient's choice to continue } \\
\text { treatment }\end{array}$ & $\begin{array}{l}70 \% \text { in Abo group } v s 31.6 \% \text { in placebo group, } \\
p=0.03 \text { chose to continue }\end{array}$ \\
\hline \multicolumn{6}{|l|}{ IncobotulinumtoxinA (Inco) } \\
\hline Jankovic et al., 2011 [131] & Blepharospasm & 109 & Up to $50 \mathrm{U} /$ eye $v s$ placebo & JRS at 6 weeks & $\begin{array}{l}\text { Significant improvement with JRS with Inco } v s \\
\text { placebo }(-0.83 v s+0.21, p<0.01)\end{array}$ \\
\hline Comella et al., 2011 [132] & Cervical dystonia & 233 & 120 or $240 \mathrm{U} v s$ placebo & TWSTRS at 4 weeks & $\begin{array}{l}\text { Significant improvement with } 120 \mathrm{U}-9.9,240 \\
\quad \mathrm{U}-10.9 \mathrm{vs} \text { placebo }-2.2, p<0.01\end{array}$ \\
\hline \multicolumn{6}{|c|}{ RimabotulinumtoxinB (Rima) } \\
\hline Lew et al., 1997 [133] & Cervical dystonia & 122 & $\begin{array}{l}2500,5000 \text {, or } 10,000 \mathrm{U} \\
\quad v s \text { placebo }\end{array}$ & TWSTRS at 4 weeks & $\begin{array}{l}\text { Significant improvement in all active groups } \\
\text { compared to placebo: } 2500 \mathrm{U}-11.6 \text {, } \\
5000 \mathrm{U}-12.5,10,000 \mathrm{U}-16.4 \mathrm{vs} \text { placebo } \\
-3.3, p<0.05\end{array}$ \\
\hline Brashear et al., 1999 [134] & Cervical dystonia & 109 & 5000 or $10,000 \mathrm{U} v s$ placebo & TWSTRS at 4 weeks & $\begin{array}{l}\text { Significant reduction with } 5000 \mathrm{U} 9.3 \\
\quad p=0.0004 \text { and } 10,000 \mathrm{U} 11.7, p=0.0115 \\
\quad v s \text { placebo } 4.3\end{array}$ \\
\hline Brin et al., 1999 [135] & Cervical dystonia & 77 & $10,000 \mathrm{U} v s$ placebo & TWSTRS at 4 weeks & $\begin{array}{l}\text { Significant improvement with Rima } v s \text { placebo } \\
\quad(-11.1 v s-2.0, p=0.0001)\end{array}$ \\
\hline
\end{tabular}

BDS = Blepharospasm Disability Scale; TWSTRS = Toronto Western Spasmodic Torticollis Rating Scale; EMG = electromyography; JRS = Jankovic Rating Scale 
Table 5 Botulinum toxin comparative trials: randomized, double-blind studies

\begin{tabular}{|c|c|c|c|c|c|}
\hline Study [ref.] & Indication & $\mathrm{n}$ & Dose & Primary Endpoint & Result \\
\hline $\begin{array}{l}\text { Nussgens and Roggenkamper, } 1997 \\
\quad[136]\end{array}$ & Blepharospasm & 212 & $\begin{array}{l}\text { Ona mean } 45.4 \mathrm{IU} v s \\
\text { Abo mean } 182.1 \mathrm{IU}\end{array}$ & Duration of effect & Similar duration \\
\hline Roggenkamper et al., 2006 [137] & Blepharospasm & 300 & $\begin{array}{l}\text { Ona mean } 40.8 \mathrm{U} v s \\
\text { Inco mean } 39.6 \mathrm{U}\end{array}$ & JRS at 3 weeks & Inco non-inferior to Ona \\
\hline Wabbels et al., 2011 [138] & Blepharospasm & 65 & $\begin{array}{l}\text { Ona mean } 29 \mathrm{U} / \text { eye } \\
\text { vs } \\
\text { Inco mean } 27 \mathrm{U} / \text { eye }\end{array}$ & BSDI at 4 weeks & No significant difference \\
\hline Odergren et al., 1998 [139] & $\begin{array}{l}\text { Cervical } \\
\text { dystonia }\end{array}$ & 73 & $\begin{array}{l}\text { Ona mean } 152 \mathrm{U} v s \\
\text { Abo mean } 477 \mathrm{U}\end{array}$ & $\begin{array}{l}\text { Tsui score at } \\
12 \text { weeks } \\
\text { Time to retreatment }\end{array}$ & $\begin{array}{l}\text { No significant difference in both } \\
\text { outcomes }\end{array}$ \\
\hline Benecke et al., 2005 [140] & $\begin{array}{l}\text { Cervical } \\
\text { dystonia }\end{array}$ & 463 & $\begin{array}{l}\text { Ona mean } 138.9 \mathrm{U} v s \\
\text { Inco mean } 140.4 \mathrm{U}\end{array}$ & TWSTRS at 4 weeks & Inco non-inferior to Ona \\
\hline Pappert et al., 2008 [141] & $\begin{array}{l}\text { Cervical } \\
\text { dystonia }\end{array}$ & 111 & $\begin{array}{l}\text { Ona } 150 \mathrm{U} v s \\
\text { Rima } 10,000 \mathrm{U}\end{array}$ & TWSTRS at 4 weeks & Rima non-inferior to Ona \\
\hline
\end{tabular}

Ona = onbotulinumtoxinA; Abo = abobotulinumtoxinA; Inco = incobotulinumtoxinA; Rima = rimabotulinumtoxinB; JRS = Jankovic Rating Scale; BDSI = Blepharospasm Disability Index; TWSTRS $=$ Toronto Western Spasmodic Torticollis Rating Scale

have largely been replaced by DBS, with the globus pallidus interna (GPi) as the target of choice. Other procedures include peripheral denervation surgery, myectomy, and other oculofacial plastic surgeries. Intrathecal baclofen infusions have been used for patients with predominantly lower limb dystonia and spasticity; new methods of delivery including intraventricular catheters are being studied.

\section{DBS}

In 2003, DBS was approved in the US by the FDA as a Humanitarian Exemption Device for dystonia. The main target of stimulation for dystonia is the GPi, although other targets are being studied. Two pivotal trials evaluating DBS for primary generalized and segmental dystonia were published in 2005 and 2006, with subsequent follow-up (Table 6) $[44,45]$. The French study involved 22 patients with generalized dystonia treated with bilateral GPi DBS [44]. At 12 months, there was significant clinical improvement in dystonia compared to the patients' pre-surgical baseline based on a blinded assessment. This benefit was sustained in a 3year follow-up study [46]. One multicenter European study involving 40 patients found significantly greater improvement with bilateral GPi stimulation versus sham treatment based on blinded clinical assessment at 3 months [45]. Subsequently, all patients completed an open-label extension of 6 months total active treatment. Further follow-up demonstrated significant improvements in dystonia at 3 and 5 years [47]. Since then, other long-term studies have been reported, including 1 retrospective cohort study of 47 DYT1-positive patients treated with GPi, followed for up to 96 months (mean, 46 months) [48]. There was significant improvement in motor scores compared to baseline for up to 7 years.
Studies have generally shown that GPi DBS is more effective for primary dystonia than secondary dystonia [49]. Predictors of benefit from DBS in primary dystonia may include younger age at onset, shorter disease duration, DYT1 -positive status, and lower baseline severity of dystonia at time of surgery [50-52]. Bilateral GPi DBS has been shown to be effective for patients with cervical dystonia who do not obtain sufficient benefit from botulinum toxin [53, 54]. Long-term benefit greater than 5 years has been reported in single-blind, open-label, and retrospective studies [54-57]. One retrospective study evaluating predictive factors of response to stimulation in cervical dystonia found that longer disease duration negatively correlated with magnitude of response, while age and disease severity did not [58]. This suggests that perhaps earlier DBS in patients with severe cervical dystonia may lead to more favorable results. Yet another study of 28 patients with idiopathic cervical dystonia and bilateral GPi DBS found no correlation between disease duration, age at onset, baseline severity, and response [57]. The presence of lateral shift was associated with less robust improvement. Patients with contractures would also be expected to respond poorly to DBS or any other therapy. Patients who have previously undergone peripheral denervation surgery for cervical dystonia may also obtain similar benefit from DBS compared to de novo patients, as demonstrated in one prospective study [59]. Other forms of segmental dystonia, which are more challenging to treat, have also responded favorably to GPi DBS. One case series of 12 patients with orofacial dystonia found significant improvement compared to baseline with sustained benefit up to 6 years [60]. GPi DBS has also been successful for severe camptocormia, for which there are limited treatment options [61].

While secondary dystonia is generally less responsive to DBS, one exception is tardive dystonia, for which there are 
Table 6 Selected studies of globus pallidus interna deep brain stimulation for dystonia

\begin{tabular}{|c|c|c|c|c|c|}
\hline Study [ref.] & Design & Type of Dystonia & Primary outcome & Follow-up & Outcome \\
\hline $\begin{array}{l}\text { Coubes et al., } 2004 \text { [142] } \\
n=31\end{array}$ & Open-label & $\begin{array}{l}\text { Primary generalized } \\
\text { dystonia }\end{array}$ & $\begin{array}{l}\text { BFMDRS } \\
\text { (movement and disability) }\end{array}$ & 2 years & $\begin{array}{l}\text { Movement: } 59.1 \pm 26.4 \text { (preoperative) } \\
\text { vs } 12.9 \pm 13.2(2 \text { years }), p<0.0001 \\
\text { Disability: } 16.5 \pm 7.8,(\text { preoperative }) v s \\
\quad 6.3 \pm 6.9(2 \text { years }), p<0.0001\end{array}$ \\
\hline $\begin{array}{l}\text { Vidailhet et al., } 2005 \text { [44] } \\
n=22\end{array}$ & $\begin{array}{l}\text { Prospective, controlled, } \\
\text { single-blind }\end{array}$ & $\begin{array}{l}\text { Primary generalized } \\
\text { dystonia }\end{array}$ & $\begin{array}{l}\text { BFMDRS } \\
\text { (movement and disability) }\end{array}$ & 12 months & $\begin{array}{l}\text { Movement: } 46.3 \pm 21.3 \text { (baseline) } v s \\
\quad 21.0 \pm 14.1 \text { ( } 12 \text { months), } p<0.001 \\
\text { Disability: } \\
11.6 \pm 5.5 \text { (baseline) } v s \\
6.5 \pm 4.9 \text { ( } 12 \text { months), } p<0.001\end{array}$ \\
\hline $\begin{array}{l}\text { Vidailhet et al., } 2007 \text { [46] } \\
n=22\end{array}$ & Follow-up & & & 3 years & $\begin{array}{l}\text { Mean movement: } 6.3 p<0.0001 \\
\text { Mean disability: } 58, p=0.0001\end{array}$ \\
\hline $\begin{array}{l}\text { Kupsch et al., } 2006[45] \\
n=40\end{array}$ & $\begin{array}{l}\text { Prospective randomized, } \\
\text { controlled, double- } \\
\text { blind, } \\
\text { sham vs stimulation }\end{array}$ & $\begin{array}{l}\text { Primary segmental } \\
\text { or generalized dystonia }\end{array}$ & BFMDRS (movement) & 3 months & $\begin{array}{l}\text { Stimulation }(-5.81 \pm 4.1) \text { vs sham } \\
\quad(1.6 \pm 4.0), p<0.01\end{array}$ \\
\hline $\begin{array}{l}\text { Volkmann et al., } 2012 \text { [47] } \\
n=40\end{array}$ & Open-label extension & & & 3 and 5 years & $\begin{array}{l}3 \text { years: }-26 \cdot 5(-61.1 \%) \\
5 \text { years: }-25.1(-57 \cdot 8 \%)\end{array}$ \\
\hline $\begin{array}{l}\text { Kiss et al., } 2007[53] \\
\mathrm{n}=10\end{array}$ & Controlled, single-blind & Cervical dystonia & $\begin{array}{l}\text { TWSTRS } \\
\text { (severity) }\end{array}$ & 12 months & $\begin{array}{l}\text { Mean (SD) of } \\
14.7(4.2) \text { presurgical to } \\
8.4(4.4) \text { at } 12 \text { months, } p=0.003\end{array}$ \\
\hline $\begin{array}{l}\text { Gruber et al., } 2009[62] \\
n=9\end{array}$ & Open-label & Tardive dystonia & $\begin{array}{l}\text { BFDMRS } \\
\text { (movement) }\end{array}$ & $\begin{array}{l}\text { 3-6 months } \\
\text { Last follow-up mean } \\
41 \text { months }\end{array}$ & $\begin{array}{l}\text { 3-6 months: } 74.1 \pm 15.8 \% \\
\quad \text { improvement } \\
\text { Last follow-up: } \\
83.0 \pm 12.2 \% \\
\text { improvement }\end{array}$ \\
\hline $\begin{array}{l}\text { Vidailhet et al., } 2009 \text { [70] } \\
\mathrm{n}=13\end{array}$ & Open-label & $\begin{array}{l}\text { Cerebral palsy } \\
\text { dystonia- } \\
\text { choreoathetosis }\end{array}$ & BFMDRS (movement) & 1 year & $\begin{array}{l}44.2(\mathrm{SD} 21.1) \text { preoperative to } 34.7 \\
(21.9) \text { at } 1 \text { year, } p=0.009\end{array}$ \\
\hline $\begin{array}{l}\text { Haridas et al., } 2011 \text { [143] } \\
\mathrm{n}=22\end{array}$ & Retrospective, chart review & $\begin{array}{l}\text { Pediatric, primary } \\
\text { generalized dystonia }\end{array}$ & BFMDRS & 1 year & Median improvement of $84 \%$ at 1 year \\
\hline $\begin{array}{l}\text { Sarubbo et al., } 2012 \text { [144] } \\
n=11\end{array}$ & Prospective, open-label & $\begin{array}{l}\text { Segmental/multisegmental } \\
\text { dystonia }\end{array}$ & $\begin{array}{l}\text { BFMDRS } \\
\text { (movement and disability) }\end{array}$ & 5 years & $\begin{array}{l}\text { Movement: } 36.9 \pm 13.4 \text { (baseline) } v s \\
14.9 \pm 10.2, p<0.001 \\
\text { Disability: } 8.9 \pm 2.6 \text { (baseline) } v s \\
\quad 3.8 \pm 4.2, p<0.002\end{array}$ \\
\hline Panov et al., 2013 [48] & Retrospective, chart review & $D Y T 1$ dystonia & $\begin{array}{l}\text { BFMDRS } \\
\text { (movement and disability) }\end{array}$ & $\begin{array}{l}2 \text { years } \\
\text { Mean follow-up } \\
46 \text { months }\end{array}$ & $\begin{array}{l}\text { At } 2 \text { years: } \\
\text { Movement score reduced to }<20 \% \text { of } \\
\text { baseline, } p=0.001 \\
\text { Disability score reduced to }<30 \% \text { of } \\
\text { baseline, } p=0.001 \\
\text { Persistent symptomatic improvement } \\
\text { at last follow-up }\end{array}$ \\
\hline
\end{tabular}

BFMDRS $=$ Burke-Fahn--Marsden Dystonia Rating Scale; TWSTRS $=$ Toronto Western Spasmodic Torticollis Rating Scale

several reports of robust improvement with long-term benefit $[62,63]$. Case reports of other forms of secondary dystonia responsive to DBS include neurodegeneration with brain iron accumulation, dopa-responsive dystonia, X-linked dystonia parkinsonism, and post-infarct hemidystonia [64-68]. Reports of response to DBS in patients with cerebral palsy have demonstrated improvement at 6 months [69] and 1 year postsurgery [70]. One open-label, nonblinded study involved 14 patients with cerebral palsy ( 8 patients younger than 16 years of age and 6 patients older than 16 years) [69]. At 6 months, there was a significant improvement in the BurkeFahn-Marsden Motor Rating Scale, Burke-Fahn-Marsden Disability Rating Scale, and Barry-Albright scores. The younger group had more significant improvement. All patients, except 1 , reported improved understandability of speech and decreased time to perform daily activities. Six patients with fixed contractures reported improvement in pain. Despite no change in objective measures of ambulation, 3 patients who were wheelchair-bound were able to stand, take steps, and assist with transfer. A prospective, multicenter pilot study involved 13 patients (median age, 33 years) with dystoniachoreathetosis cerebral palsy and utilized masked assessments to evaluate the efficacy of bilateral pallidal stimulation [70]. These included patients with severe dystonia-choreathetosis, little or no cognitive impairment, and only slight abnormalities on T1-weighted magnetic resonance imaging. At 1 year, the mean Burke-Fahn-Marsden Dystonia Rating Scale movement score improved by $24.4 \%$ - a significant improvement compared to baseline. Pain, mental health-related quality of life, and functional disability also significantly improved. The improvement, however, was heterogeneous, with some patients having little or no benefit. One concern regarding DBS in secondary dystonia is the accuracy of lead placement due to degeneration and thus smaller GPi targets. A 
retrospective review of 88 electrodes in 42 patients found no significant difference in lead placement in patients with primary, secondary, or neurodegeneration with brain iron accumulation-related dystonia [71]. This suggests that differential response to DBS in secondary dystonia is unlikely related to difficulties with lead placement. Response to DBS in patients with secondary dystonia can be variable because of other associated neurologic impairments contributing to disability, as well as degeneration or injury to the globus pallidus in secondary cases. Discussing goals of therapy and potentially limited response to DBS is imperative prior to surgery for these patients.

Studies of neuropsychological changes after GPi DBS for dystonia have evaluated both mood and cognition [72]. No significant change has been demonstrated in cognition postoperatively in studies involving primary dystonia, tardive dystonia, and cerebral palsy. Up to 3 years of follow up have been included in some studies. With regard to mood, depression generally is not worsened, and some studies have shown improvement. However, there have been reports of 2 suicides following pallidal DBS for dystonia [73]. These studies generally included patients without cognitive dysfunction or severe depression prior to surgery, and thus detailed neuropsychological testing preoperatively is still recommended in all patients.

While DBS has been reported in many series to be effective for up to 3 years in patients with primary dystonia, there are potential complications that may occur and were reported in a review of long-term management of DBS in dystonia [74]. These adverse effects can be categorized as stimulation- and hardware-related. Stimulation-related adverse effects in GPi stimulation include speech abnormalities (dysarthria, dysphonia, stuttering), paresthesias, perioral tingling, and incoordination [74]. There are reports of parkinsonism following pallidal DBS for dystonia. One retrospective study identified a hypokinetic gait in in 6/71 patients characterized by a shuffling gait and difficulty with turns [75]. Increasing the voltage triggered freezing of gait, which resolved with turning the stimulator off. Others have reported micrographia, rigidity, and postural instability [76, 77]. Hardware-related complications include skin infection and erosion, implantable pulse generator malfunction/hematoma/infection, electrode damage, lead fracture/misplacement, or extension wire failure. Although earlier studies suggested that lead fractures were more common in dystonia patients, more recent data did not report greater hardware complications in this patient population compared with other movement disorders [74].

A challenge with DBS for dystonia is the relatively fast rate of battery depletion in patients who generally require high settings to control their symptoms [78, 79]. Rechargeable neurostimulators may be a reasonable option for these patients and eliminate the need for replacement batteries every few years $[80,81]$. One report of 30 patients with a rechargeable device described high patient satisfaction and a low complication rate $[80]$. The caregivers were responsible for recharging in $80 \%$ of cases, and recharging complications were reported in $36 \%$ of cases. Recharging complications included problems with the recharger, displacement of the adaptor in front of the stimulator and poor compliance with recharging. Despite these complications, 24/25 patients would recommend a rechargeable device to other patients. While rechargeable stimulators do have their benefit, recharging can be cumbersome for the patient requiring the use of a harness. Depending on the level of stimulation, recharging may need to be done every few days for hours at a time.

While GPi is the preferred DBS target for dystonia, other sites are being used and studied as an alternative in some groups of patients. For example, the Vim nucleus of the thalamus has been reported to be effective for patients with dystonic tremor, although in small numbers ( $\sim 30$ cases $)$ [82]. The subthalamic nucleus (STN) has been studied as an alternative target for primary and tardive dystonia [83-86]. Most of these studies have included small numbers of patients, that is, fewer than 10 patients. One study involving 27 patients with primary dystonia assessed the long-term efficacy of bilateral STN stimulation up to 10 years postoperatively [86]. Based on blinded video assessments, there was significant improvement on the Burke-Fahn-Marsden Dystonia Rating Scale up to 1 year, with a subsequent plateau and maintenance of benefit for up to 3-10 years. Some potential benefits with STN DBS that have been suggested include the lack of bradykinesia as a side effect, immediate symptomatic improvement after programming, and lower settings resulting in prolonged battery life [84]. Success with both bilateral pallidal and STN DBS in patients with a combination of dystonia and parkinsonism has also been reported [87, 88].

\section{Ablative Procedures}

Ablative procedures such as thalamotomy and pallidotomy for dystonia have been generally replaced by GPi DBS, which, unlike pallidotomy, can be adjusted to improve response and minimize side effects. While there are no controlled studies evaluating pallidotomy for dystonia, case series have demonstrated the efficacy of this procedure $[89,90]$. There is the potential for irreversible side effects, such as dysarthria, with bilateral procedures. Nonetheless, there may still be a role for pallidotomy in individual cases, such as for those patients with previous hardware complications or infections from DBS, or for those individuals who do not have access to postoperative programming. In patients who have already undergone pallidotomy, but have progressive symptoms, successful subsequent DBS of the STN [91] and even GPi have been reported [92]. 


\section{Peripheral Denervation}

Selective peripheral denervation surgery, a procedure that targets specific muscles causing dystonia, has been reported to be effective for botulinum toxin-resistant cervical dystonia in prospective and retrospective case series [93-96]. A study comparing selective peripheral denervation with GPi DBS in 24 cervical dystonia patients demonstrated no significant difference between groups based on clinical examination after a mean follow-up of 29.5 months [97]. The DBS group, however, had a nonsignificant greater reduction in pain. Potential side effects for selective peripheral denervation include dysphagia and re-innervation leading to the return of symptoms [95].

Intrathecal Baclofen

Intrathecal baclofen (ITB) pumps have been used for the treatment of generalized dystonia [97-101]. The first successful use of ITB was described at Baylor College of Medicine in a patient with refractory axial dystonia [102]. ITB may be particularly efficacious in patients with predominant lower limb dystonia and associated spasticity. ITB may be considered in patients who require higher doses of baclofen with increasing side effects from oral baclofen. The use of ITB is associated with several challenges that require a team of care providers [103]. Potential side effects include drowsiness, decreased head and trunk control, and constipation. Surgical complications include cerebrospinal fluid leaks, infections, and catheter-related problems, such as migration and fractures. Pump failure can lead to baclofen withdrawal leading to seizures and life-threatening dystonic storms. Optimal dosing, concentration, continuous versus bolus infusion, and programmable versus non-programmable pumps are all factors that still need clarification.

\section{Intraventricular Baclofen}

Intraventricular baclofen (IVB), with catheter placement in the lateral ventricle, has been proposed as an alternative to ITB for intractable dystonia [104-106]. IVB may be an alternative for patients with spinal anomalies that make placement of ITB difficult, or for those who have had multiple complications from ITB requiring revisions. Furthermore, this mode of delivery may result in a higher concentration of baclofen over the cortex. One case series comparing 30 IVB patients with 33 ITB patients found a similar safety profile in both procedures [106]. Another report of 22 patients with spasticity or dystonia who had ITB complicated by multiple revisions and then transitioned to IVB, found fewer surgical revisions with IVB [104].
Oculoplastic Surgery

Oculoplastic surgeries for blepharospasm have been performed in patients with insufficient response to botulinum toxin. One such procedure is eyelid protractor myectomy, which was reported to provide subjective short- and longterm benefit in $94 \%$ of 54 patients who underwent surgery [107]. Another study of patients with blepharospasm associated with apraxia of eyelid opening and who were resistant to botulinum toxin reported resolution of apraxia of eyelid opening in $33 \%$ of patients with this procedure [108]. Furthermore, in 20/30 patients there was a greater duration of benefit of botulinum toxin postoperatively. Potential complications of myectomy include forehead numbness, keratitis, and the need for surgical revisions. Other procedures that have been employed include frontalis sling operations [109] and brow lifting for apraxia of eyelid opening [110].

\section{Physical and Other Modes of Therapy}

Devices and braces that take advantage of sensory tricks can be crafted to alleviate focal dystonia, such as dental implants for musicians with embouchure dystonia [111]. Eyelid crutches can be attached to glasses to help prop the eyelids open in patients with blepharospasm or in those who experience ptosis after botulinum toxin injection. Physical therapy can be added to treatment regimens for cervical dystonia to improve pain and disability [112]. Studies have evaluated the benefit of a combination of physical therapy and botulinum toxin for dystonia. One study involving 40 patients with cervical dystonia found that patients receiving botulinum toxin and physical therapy combined had a longer duration of benefit of toxin, lower doses of toxin, and greater improvement in disability and pain compared with those receiving toxin alone [113]. Interventions with limited reported benefit for focal hand dystonia include sensory retraining by practicing braille reading, splinting, limb immobilization, biofeedback, and transcutaneous electrical nerve stimulation [114]. Several other modes of therapy are being studied. A crossover study of 25 patients with focal hand dystonia and cervical dystonia found an improvement in pain and sensory discrimination when treated with KinesioTaping compared with sham taping [115]. Studies implementing noninvasive transcranial magnetic stimulation have demonstrated small transient benefits in measurements of focal limb dystonia, presumably by restoring cortical inhibition [116, 117]. Transcranial alternating current stimulation was demonstrated to have significant benefit compared with sham treatment in a patient with intractable cervical dystonia, lasting for 30 days [118]. Further studies are needed to confirm the clinical utility of these noninvasive stimulation treatments. 


\section{Conclusion}

There is a wide range of therapeutic options available to patients with dystonia. With appropriate selection of the treatment modality patients may experience marked improvement in quality of life, allowing them to return to their employment and engage in daily actives, such as reading, watching television, and driving. Goals of treatment including pain relief, and specific functional improvements are important to identify at the outset. Often, a combination of therapies, including physical therapy, oral medications, botulinum toxin, and surgical procedures, may be needed to optimize treatment response. As more is learned about dystonia, including gene discovery leading to further understanding of underlying molecular pathophysiology, more effective treatments, including disease-modifying therapies, will, hopefully, be developed.

\section{References}

1. Albanese A, Bhatia K, Bressman SB, et al. Phenomenology and classification of dystonia: A consensus update. Mov Disord 2013;28:863-873.

2. Charlesworth G, Bhatia KP, Wood NW. The genetics of dystonia: new twists in an old tale. Brain 2013;136:2017-2037.

3. Ozelius LJ, Lubarr N, Bressman SB. Milestones in dystonia. Mov Disord 2011;26:1106-1126.

4. Pavese N. Dystonia: hopes for a better diagnosis and a treatment with long-lasting effect. Brain 2013;136:694-695.

5. Patel N, Jankovic J, Hallett M. Sensory aspects of movement disorders. Lancet Neurol 2013 (in press).

6. Jankovic J. Medical treatment of dystonia. Mov Disord 2013;28: 1001-1012

7. Burke RE, Fahn S, Marsden CD. Torsion dystonia: a double-blind, prospective trial of high-dosage trihexyphenidyl. Neurology 1986;36:160-164.

8. Taylor AE, Lang AE, Saint-Cyr JA, Riley DE, Ranawaya R. Cognitive processes in idiopathic dystonia treated with high-dose anticholinergic therapy: implications for treatment strategies. Clin Neuropharmacol 1991;14:62-77.

9. Greene PE, Fahn S. Baclofen in the treatment of idiopathic dystonia in children. Mov Disord 1992;7:48-52.

10. Karp BI, Goldstein SR, Chen R, et al. An open trial of clozapine for dystonia. Mov Disord 1999;14:652-657.

11. Trugman JM, Leadbetter R, Zalis ME, Burgdorf RO, Wooten GF. Treatment of severe axial tardive dystonia with clozapine: case report and hypothesis. Mov Disord 1994;9:441-446.

12. Kenney C, Hunter C, Jankovic J. Long-term tolerability of tetrabenazine in the treatment of hyperkinetic movement disorders. Mov Disord 2007;22:193-197.

13. Jankovic J, Clarence-Smith K. Tetrabenazine for the treatment of chorea and other hyperkinetic movement disorders. Expert Rev Neurother 2011;11:1509-1523.

14. Jimenez-Shahed, Jankovic J. Tetrabenazine for treatment of chorea associated with Huntington's disease. Exp Opin Orphan Drugs 2013 (in press)

15. Waln O, Jankovic J. Zolpidem improves tardive dyskinesia with and without akathisia. Mov Disord 2013 May 1 [Epub ahead of print].
16. Miyazaki Y, Sako W, Asanuma K, et al. Efficacy of zolpidem for dystonia: a study among different subtypes. Front Neurol 2012;3:58.

17. Kang UJ, Burke RE, Fahn S. Tardive dystonia. Adv Neurol 1988;50:415-429.

18. Trender-Gerhard I, Sweeney MG, Schwingenschuh P, et al. Autosomal-dominant GTPCH1-deficient DRD: clinical characteristics and long-term outcome of 34 patients. J Neurol Neurosurg Psychiatry 2009;80:839-845.

19. Nygaard TG, Marsden CD, Fahn S. Dopa-responsive dystonia: long-term treatment response and prognosis. Neurology 1991;41: 174-181

20. Hwang WJ, Calne DB, Tsui JK, de la Fuente-Fernandez R. The long-term response to levodopa in dopa-responsive dystonia. Parkinsonism Relat Disord 2001;8:1-5.

21. Friedman J, Roze E, Abdenur JE, et al. Sepiapterin reductase deficiency: a treatable mimic of cerebral palsy. Ann Neurol 2012;71:520-530.

22. Pearl PL, Taylor JL, Trzcinski S, Sokohl A. The pediatric neurotransmitter disorders. J Child Neurol 2007;22:606-616.

23. Kitahara M, Shimohata T, Tokunaga J, Nishizawa M. Cervical dystonia associated with spinocerebellar ataxia type 2 successfully treated with levodopa: a case report. Mov Disord 2009;24:2163-2164.

24. Bernard G, Vanasse M, Chouinard S. A case of secondary dystonia responding to levodopa. J Child Neurol 2010;25:780-781.

25. Kinugawa K, et al. Myoclonus-dystonia: an update. Mov Disord 2009;24:479-489.

26. Frucht SJ, Bordelon Y, Houghton WH, Reardan D. A pilot tolerability and efficacy trial of sodium oxybate in ethanol-responsive movement disorders. Mov Disord 2005;20:1330-1337.

27. Yang Y, Su Y, Guo Y, et al. Oxcarbazepine versus carbamazepine in the treatment of paroxysmal kinesigenic dyskinesia. Int J Neurosci 2012;122:719-722.

28. Ramirez-Castaneda, Jankovic J, Comella C, Dashtipour K, Fernandez HH, Mari Z. Diffusion, spread, dilution, and migration of botulinum toxin. Mov Disord 2013 Jul 18 [Epub ahead of print].

29. Dressler D. Five-year experience with incobotulinumtoxinA (Xeomin $\left({ }^{\circledR}\right)$ ): the first botulinum toxin drug free of complexing proteins. Eur J Neurol 2012;19:385-389.

30. Tintner R, Gross R, Winzer UF, Smalky KA, Jankovic J. Autonomic function after botulinum toxin type A or B: a double-blind, randomized trial. Neurology 2005;65:765-767.

31. Simpson DM, Blitzer A, Brashear A, et al. Assessment: Botulinum neurotoxin for the treatment of movement disorders (an evidencebased review): report of the Therapeutics and Technology Assessment Subcommittee of the American Academy of Neurology. Neurology 2008;70:1699-1706.

32. Hallett M, Albanese A, Dressler D, et al. Evidence-based review and assessment of botulinum neurotoxin for the treatment of movement disorders. Toxicon 2013;67:94-114.

33. Thenganatt MA, Fahn S. Botulinum toxin for the treatment of movement disorders. Curr Neurol Neurosci Rep 2012;12:399-409.

34. Colosimo C, Tiple D, Berardelli A. Efficacy and safety of long-term botulinum toxin treatment in craniocervical dystonia: a systematic review. Neurotox Res 2012;22:265-273.

35. Ramirez-Castaneda J, Jankovic J. Long-term efficacy and safety of botulinum toxin injections in dystonia. Toxins (Basel) 2013;5:249-266.

36. Baizabal-Carvallo JF, Jankovic J, Feld J. Flu-like symptoms and associated immunological response following therapy with botulinum toxins. Neurotox Res 2013;24:298-306.

37. Misra VP, Ehler E, Zakine B, et al. Factors influencing response to Botulinum toxin type A in patients with idiopathic cervical dystonia: results from an international observational study. BMJ Open 2012;2.

38. Nijmeijer SW, Koelman JH, Kamphuis DJ, Tijssen MA. Muscle selection for treatment of cervical dystonia with botulinum toxin - a systematic review. Parkinsonism Relat Disord 2012;18:731-716. 
39. Bhidayasiri R. Treatment of complex cervical dystonia with botulinum toxin: involvement of deep-cervical muscles may contribute to suboptimal responses. Parkinsonism Relat Disord 2011;17(Suppl. 1):S20-S24.

40. Jankovic J, Vuong KD, Ahsan J. Comparison of efficacy and immunogenicity of original versus current botulinum toxin in cervical dystonia. Neurology 2003;60:1186-1188.

41. Zoons E, Dijkgraaf MG, Dijk JM, van Schaik IN, Tijssen MA. Botulinum toxin as treatment for focal dystonia: a systematic review of the pharmaco-therapeutic and pharmaco-economic value. J Neurol 2012;259:2519-2526.

42. Koshy JC, Sharabi SE, Feldman EM, et al. Effect of dietary zinc and phytase supplementation on botulinum toxin treatments. J Drugs Dermatol 2012;11:507-512.

43. Park TY, Shin MJ, Park SD, Lee SK. Alleviation of abnormal synaptic neurotransmitter release by cell-permeable form of the truncated SNAP-25 upon transcutaneous delivery. Neurosci Lett 2013;543:52-57.

44. Vidailhet M, Vercueil L, Houeto JL, et al. Bilateral deep-brain stimulation of the globus pallidus in primary generalized dystonia. N Engl J Med 2005;352:459-467.

45. Kupsch A, Benecke R, Muller J, et al. Pallidal deep-brain stimulation in primary generalized or segmental dystonia. N Engl J Med 2006;355:1978-1990.

46. Vidailhet M, Vercueil L, Houeto JL, et al. Bilateral, pallidal, deepbrain stimulation in primary generalised dystonia: a prospective 3 year follow-up study. Lancet Neurol 2007;6:223-229.

47. Volkmann J, Wolters A, Kupsch A, et al. Pallidal deep brain stimulation in patients with primary generalised or segmental dystonia: 5-year follow-up of a randomised trial. Lancet Neurol 2012;11: 1029-1038.

48. Panov F, Gologorsky Y, Connors G, et al. Deep brain stimulation in DYT1 Dystonia: A 10-year experience. Neurosurgery 2013;73:86-93.

49. Speelman JD, Contarino MF, Schuurman PR, Tijssen MA, de Bie RM. Deep brain stimulation for dystonia: patient selection and outcomes. Eur J Neurol 2010;17(Suppl. 1):102-106.

50. Andrews C, Aviles-Olmos I, Hariz M, Foltynie T. Which patients with dystonia benefit from deep brain stimulation? A metaregression of individual patient outcomes. J Neurol Neurosurg Psychiatry 2010;81:1383-1389.

51. Markun LC, Starr PA, Air EL, et al. Shorter disease duration correlates with improved long-term deep brain stimulation outcomes in young-onset DYT1 dystonia. Neurosurgery 2012;71: 325-330.

52. Isaias IU, Volkmann J, Kupsch A, et al. Factors predicting protracted improvement after pallidal DBS for primary dystonia: the role of age and disease duration. J Neurol 2011;258:1469-1476.

53. Kiss ZH, Doig-Beyaert K, Eliasziw M, et al. The Canadian multicentre study of deep brain stimulation for cervical dystonia. Brain 2007;130:2879-2886.

54. Hung SW, Hamani C, Lozano AM, et al. Long-term outcome of bilateral pallidal deep brain stimulation for primary cervical dystonia. Neurology 2007;68:457-459.

55. Walsh RA, Sidiropoulos C, Lozano AM, et al. Bilateral pallidal stimulation in cervical dystonia: blinded evidence of benefit beyond 5 years. Brain 2013;136:761-769.

56. Skogseid IM, Ramm-Pettersen J, Volkmann J, et al. Good long-term efficacy of pallidal stimulation in cervical dystonia: a prospective, observer-blinded study. Eur J Neurol 2012;19:610-615.

57. Witt JL, Moro E, Ash RS, et al. Predictive factors of outcome in primary cervical dystonia following pallidal deep brain stimulation. Mov Disord 2013 Jun 20 [Epub ahead of print].

58. Yamada K, Hamasaki T, Hasegawa Y, Kuratsu J. Long disease duration interferes with therapeutic effect of globus pallidus internus pallidal stimulation in primary cervical dystonia. Neuromodulation 2013;16:219-225.
59. Capelle HH, Blahak C, Schrader C, et al. Bilateral deep brain stimulation for cervical dystonia in patients with previous peripheral surgery. Mov Disord 2012;27:301-304.

60. Reese R, Gruber D, Schoenecker T, et al. Long-term clinical outcome in meige syndrome treated with internal pallidum deep brain stimulation. Mov Disord 2011;26:691-698.

61. Hagenacker T, Gerwig M, Gasser T, et al. Pallidal deep brain stimulation relieves camptocormia in primary dystonia. J Neurol 2013;260:1833-1837.

62. Gruber D, Trottenberg T, Kivi A, et al. Long-term effects of pallidal deep brain stimulation in tardive dystonia. Neurology 2009;73:5358.

63. Chang EF, Schrock LE, Starr PA, Ostrem JL. Long-term benefit sustained after bilateral pallidal deep brain stimulation in patients with refractory tardive dystonia. Stereotact Funct Neurosurg 2010;88:304-310.

64. Tormenti MJ, Tomycz ND, Coffman KA, et al. Bilateral subthalamic nucleus deep brain stimulation for dopa-responsive dystonia in a 6-year-old child. J Neurosurg Pediatr 2011;7:650-653.

65. Tierney TS, Lozano AM. Surgical treatment for secondary dystonia. Mov Disord 2012;27:1598-1605.

66. Aguilar JA, Vesagas TS, Jamora RD, et al. The promise of deep brain stimulation in X-linked dystonia parkinsonism. Int J Neurosci 2011;121(Suppl.) 1:57-63.

67. Krause M, Fogel W, Tronnier V, et al. Long-term benefit to pallidal deep brain stimulation in a case of dystonia secondary to pantothenate kinase-associated neurodegeneration. Mov Disord 2006;21: 2255-2257.

68. Witt J, Starr PA, Ostrem JL. Use of pallidal deep brain stimulation in postinfarct hemidystonia. Stereotact Funct Neurosurg 2013;91:243247.

69. Marks WA, Honeycutt J, Acosta F, Jr, et al. Dystonia due to cerebral palsy responds to deep brain stimulation of the globus pallidus internus. Mov Disord 2011;26:1748-1751.

70. Vidailhet M, Yelnik J, Lagrange C, et al. Bilateral pallidal deep brain stimulation for the treatment of patients with dystoniachoreoathetosis cerebral palsy: a prospective pilot study. Lancet Neurol 2009;8:709-717.

71. Lumsden DE, Ashmore J, Charles-Edwards G, et al. Accuracy of stimulating electrode placement in paediatric pallidal deep brain stimulation for primary and secondary dystonia. Acta Neurochir (Wien) 2013;155:823-836.

72. Jahanshahi M, Czernecki V, Zurowski AM. Neuropsychological, neuropsychiatric, and quality of life issues in DBS for dystonia. Mov Disord 2011;26(Suppl. 1):S63-S78.

73. Foncke EM, Schuurman PR, Speelman JD. Suicide after deep brain stimulation of the internal globus pallidus for dystonia. Neurology 2006;66:142-143.

74. Tagliati M, Krack P, Volkmann J, et al. Long-Term management of DBS in dystonia: response to stimulation, adverse events, battery changes, and special considerations. Mov Disord 2011;26(Suppl. 1):S54-S62.

75. Schrader C, Capelle HH, Kinfe TM, et al. GPi-DBS may induce a hypokinetic gait disorder with freezing of gait in patients with dystonia. Neurology 2011;77:483-488.

76. Blahak C, Capelle HH, Baezner H, et al. Micrographia induced by pallidal DBS for segmental dystonia: a subtle sign of hypokinesia? J Neural Transm 2011;118:549-553.

77. Zauber SE, Watson N, Comella CL, Bakay RA, Metman LV. Stimulation-induced parkinsonism after posteroventral deep brain stimulation of the globus pallidus internus for craniocervical dystonia. J Neurosurg 2009;110:229-233.

78. Lumsden DE, Kaminska M, Tustin K, et al. Battery life following pallidal deep brain stimulation (DBS) in children and young people with severe primary and secondary dystonia. Childs Nerv Syst 2012;28:1091-1097. 
79. Blahak C, Capelle HH, Baezner H, et al. Battery lifetime in pallidal deep brain stimulation for dystonia. Eur J Neurol 2011;18:872-875.

80. Kaminska M, Lumsden DE, Ashkan K, et al. Rechargeable deep brain stimulators in the management of paediatric dystonia: well tolerated with a low complication rate. Stereotact Funct Neurosurg 2012;90:233-239.

81. Gillies MJ, Joint C, Forrow B, et al. Rechargeable vs. Nonrechargeable Internal Pulse Generators in the Management of Dystonia. Neuromodulation 2013;16:226-229.

82. Morishita T, Foote KD, Haq IU, et al. Should we consider Vim thalamic deep brain stimulation for select cases of severe refractory dystonic tremor. Stereotact Funct Neurosurg 2010;88:98-104.

83. Ostrem JL, Racine CA, Glass GA, et al. Subthalamic nucleus deep brain stimulation in primary cervical dystonia. Neurology 2011;76: 870-878.

84. Sun B, Chen S, Zhan S, Le W, Krahl SE. Subthalamic nucleus stimulation for primary dystonia and tardive dystonia. Acta Neurochir Suppl 2007;97:207-214.

85. Schjerling L, Hjermind LE, Jespersen B, et al. A randomized double-blind crossover trial comparing subthalamic and pallidal deep brain stimulation for dystonia. J Neurosurg 2013. doi:10. 3171/2013.8.JNS13844

86. Cao C, Pan Y, Li D, et al. Subthalamus deep brain stimulation for primary dystonia patients: A long-term follow-up study. Mov Disord 2013 Jul 16 [Epub ahead of print].

87. Wohrle JC, Blahak C, Capelle HH, et al. Combined pallidal and subthalamic nucleus stimulation in sporadic dystonia-parkinsonism. J Neurosurg 2012;116:95-98.

88. Baizabal-Carvallo JF, Roze E, Aya-Kombo M, et al. Combined pallidal and subthalamic nucleus deep brain stimulation in secondary dystonia-parkinsonism. Parkinsonism Relat Disord 2013;19: 566-568.

89. Gross RE. What happened to posteroventral pallidotomy for Parkinson's disease and dystonia? Neurotherapeutics 2008;5:281293.

90. Ondo WG, Desaloms JM, Jankovic J, Grossman RG. Pallidotomy for generalized dystonia. Mov Disord 1998;13:693-698.

91. Fonoff ET, Campos WK, Mandel M, Alho EJ, Teixeira MJ. Bilateral subthalamic nucleus stimulation for generalized dystonia after bilateral pallidotomy. Mov Disord 2012;27:1559-1563.

92. Waln O, Jankovic J. Bilateral globus pallidus internus deep brain stimulation after bilateral pallidotomy in a patient with generalized early-onset primary dystonia. Mov Disord 2013;28:1162-1163.

93. Ford B, Louis ED, Greene P, Fahn S. Outcome of selective ramisectomy for botulinum toxin resistant torticollis. J Neurol Neurosurg Psychiatry 1998;65:472-478.

94. Munchau A, Palmer JD, Dressler D, et al. Prospective study of selective peripheral denervation for botulinum-toxin resistant patients with cervical dystonia. Brain 2001;124:769-783.

95. Braun V, Richter HP. Selective peripheral denervation for spasmodic torticollis: 13-year experience with 155 patients. J Neurosurg 2002;97(2 Suppl.):207-212.

96. Cohen-Gadol AA, Ahlskog JE, Matsumoto JY, et al. Selective peripheral denervation for the treatment of intractable spasmodic torticollis: experience with 168 patients at the Mayo Clinic. J Neurosurg 2003;98:1247-1254.

97. Huh R, Han IB, Chung M, Chung S. Comparison of treatment results between selective peripheral denervation and deep brain stimulation in patients with cervical dystonia. Stereotact Funct Neurosurg 2010;88:234-238.

98. Pin TW, McCartney L, Lewis J, Waugh MC. Use of intrathecal baclofen therapy in ambulant children and adolescents with spasticity and dystonia of cerebral origin: a systematic review. Dev Med Child Neurol 2011;53:885-895.

99. Hou JG, Ondo W, Jankovic J. Intrathecal baclofen for dystonia. Mov Disord 2001;16:1201-1202.
100. Albright AL, Barry MJ, Shafton DH, Ferson SS. Intrathecal baclofen for generalized dystonia. Dev Med Child Neurol 2001;43:652-657.

101. Uchiyama T, Nakanishi K, Fukawa N, et al. Neuromodulation using intrathecal baclofen therapy for spasticity and dystonia. Neurol Med Chir (Tokyo) 2012;52:463-469.

102. Narayan RK, Loubser PG, Jankovic J, Donovan WH, Bontke CF. Intrathecal baclofen for intractable axial dystonia. Neurology 1991;41:1141-1142.

103. Brennan PM, Whittle IR. Intrathecal baclofen therapy for neurological disorders: a sound knowledge base but many challenges remain. Br J Neurosurg 2008;22:508-519.

104. Turner M, Nguyen HS, Cohen-Gadol AA. Intraventricular baclofen as an alternative to intrathecal baclofen for intractable spasticity or dystonia: outcomes and technical considerations. J Neurosurg Pediatr 2012;10:315-319.

105. Albright AL, Ferson SS. Intraventricular baclofen for dystonia: techniques and outcomes. Clinical article. J Neurosurg Pediatr 2009;3:11-14

106. Rocque BG, Leland Albright A. Intraventricular vs intrathecal baclofen for secondary dystonia: a comparison of complications. Neurosurgery 2012;70(2 Suppl. Operative):321-325.

107. Chapman KL, Bartley GB, Waller RR, Hodge DO. Follow-up of patients with essential blepharospasm who underwent eyelid protractor myectomy at the Mayo Clinic from 1980 through 1995. Ophthal Plast Reconstr Surg 1999;15:106-110.

108. Georgescu D, Vagefi MR, McMullan TF, McCann JD, Anderson RL. Upper eyelid myectomy in blepharospasm with associated apraxia of lid opening. Am J Ophthalmol 2008; $145: 541-547$.

109. Wabbels B, Roggenkamper P. Long-term follow-up of patients with frontalis sling operation in the treatment of essential blepharospasm unresponsive to botulinum toxin therapy. Graefes Arch Clin Exp Ophthalmol 2007;245:45-50

110. Nicoletti AG, Pereira IC, Matayoshi S. Browlifting as an alternative procedure for apraxia of eyelid opening. Ophthal Plast Reconstr Surg 2009;25:46-47.

111. Satoh M, Narita M, Tomimoto H. Three cases of focal embouchure dystonia: classifications and successful therapy using a dental splint. Eur Neurol 2011;66:85-90.

112. Queiroz MA, Chien HF, Sekeff-Sallem FA, Barbosa ER. Physical therapy program for cervical dystonia: a study of 20 cases. Funct Neurol 2012;27:187-192.

113. Tassorelli C, Mancini F, Balloni L, et al. Botulinum toxin and neuromotor rehabilitation: An integrated approach to idiopathic cervical dystonia. Mov Disord 2006;21:2240-2243.

114. Cogiamanian F, Barbieri S, Priori A. Novel nonpharmacologic perspectives for the treatment of task-specific focal hand dystonia. J Hand Ther 2009;22:156-61.

115. Pelosin E, Avanzino L, Marchese R, et al. Kinesio taping reduces pain and modulates sensory function in patients with focal dystonia: a randomized crossover pilot study. Neurorehabil Neural Repair 2013;27:722-731.

116. Kimberley TJ, Borich MR, Arora S, Siebner HR. Multiple sessions of low-frequency repetitive transcranial magnetic stimulation in focal hand dystonia: clinical and physiological effects. Restor Neurol Neurosci 2013; 31:533-542.

117. Kieslinger K, Holler Y, Bergmann J, Golaszewski S, Staffen W. Successful treatment of musician's dystonia using repetitive transcranial magnetic stimulation. Clin Neurol Neurosurg 2013; 115: 1871-1872

118. Angelakis E, Liouta E, Andreadis N, et al. Transcranial alternating current stimulation reduces symptoms in intractable idiopathic cervical dystonia: a case study. Neuroscience letters 2013;533:39-43.

119. Jankovic J, Orman J. Botulinum A toxin for cranial-cervical dystonia: a double-blind, placebo-controlled study. Neurology 1987;37:616-623. 
120. Greene P, Kang U, Fahn S, et al. Double-blind, placebo-controlled trial of botulinum toxin injections for the treatment of spasmodic torticollis. Neurology 1990;40:1213-1218.

121. Yoshimura DM, Aminoff MJ, Olney RK. Botulinum toxin therapy for limb dystonias. Neurology 1992;42:627-630.

122. Tsui JK, Bhatt M, Calne S, Calne DB. Botulinum toxin in the treatment of writer's cramp: a double-blind study. Neurology 1993;43:183-185.

123. Cole R, Hallett M, Cohen LG. Double-blind trial of botulinum toxin for treatment of focal hand dystonia. Mov Disord 1995; 10:466-471.

124. Troung DD, Rontal M, Rolnick M, Aronson AE, Mistura K. Double-blind controlled study of botulinum toxin in adductor spasmodic dysphonia. Laryngoscope 1991;101:630-634.

125. Truong D, Comella C, Fernandez HH, Ondo WG, Dysport Benign Essential Blepharospasm Study G. Efficacy and safety of purified botulinum toxin type A (Dysport) for the treatment of benign essential blepharospasm: a randomized, placebo-controlled, phase II trial. Parkinsonism Relat Disord 2008;14:407-414.

126. Poewe W, Deuschl G, Nebe A, et al. What is the optimal dose of botulinum toxin A in the treatment of cervical dystonia? Results of a double blind, placebo controlled, dose ranging study using Dysport. German Dystonia Study Group. J Neurol Neurosurg Psychiatry 1998;64:13-17.

127. Truong D, Duane DD, Jankovic J, et al. Efficacy and safety of botulinum type A toxin (Dysport) in cervical dystonia: results of the first US randomized, double-blind, placebo-controlled study. Mov Disord 2005;20:783-791.

128. Truong D, Brodsky M, Lew M, et al. Long-term efficacy and safety of botulinum toxin type A (Dysport) in cervical dystonia. Parkinsonism Relat Disord 2010;16:316-323.

129. Lee SJ, McCall WD, Jr., Kim YK, Chung SC, Chung JW. Effect of botulinum toxin injection on nocturnal bruxism: a randomized controlled trial. Am J Phys Med Rehabil 2010;89:16-23.

130. Kruisdijk JJ, Koelman JH, Ongerboer de Visser BW, de Haan RJ, Speelman JD. Botulinum toxin for writer's cramp: a randomised, placebo-controlled trial and 1-year follow-up. J Neurol Neurosurg Psychiatry 2007;78:264-270.

131. Jankovic J, Comella C, Hanschmann A, Grafe S. Efficacy and safety of incobotulinumtoxinA (NT 201, Xeomin) in the treatment of blepharospasm-a randomized trial. Mov Disord 2011;26:1521-1528.

132. Comella CL, Jankovic J, Truong DD, et al. Efficacy and safety of incobotulinumtoxinA (NT 201, XEOMIN ${ }^{\circledR}$, botulinum neurotoxin type A, without accessory proteins) in patients with cervical dystonia. J Neurol Sci 2011;308:103-109.

133. Lew MF, Adornato BT, Duane DD, et al. Botulinum toxin type B: a double-blind, placebo-controlled, safety and efficacy study in cervical dystonia. Neurology 1997;49:701-707.

134. Brashear A, Lew MF, Dykstra DD, et al. Safety and efficacy of NeuroBloc (botulinum toxin type B) in type A-responsive cervical dystonia. Neurology 1999;53:1439-1446.

135. Brin MF, Lew MF, Adler CH, et al. Safety and efficacy of NeuroBloc (botulinum toxin type B) in type A-resistant cervical dystonia. Neurology 1999;53:1431-1438.

136. Nussgens Z, Roggenkamper P. Comparison of two botulinum-toxin preparations in the treatment of essential blepharospasm. Graefes Arch Clin Exp Ophthalmol 1997;235:197-199.

137. Roggenkamper P, Jost WH, Bihari K, et al. Efficacy and safety of a new Botulinum Toxin Type A free of complexing proteins in the treatment of blepharospasm. J Neural Transm 2006;113:303-312.

138. Wabbels B, Reichel G, Fulford-Smith A, Wright N, Roggenkamper P. Double-blind, randomised, parallel group pilot study comparing two botulinum toxin type A products for the treatment of blepharospasm. J Neural Transm 2011;118:233-239.

139. Odergren T, Hjaltason H, Kaakkola S, et al. A double blind, randomised, parallel group study to investigate the dose equivalence of Dysport and Botox in the treatment of cervical dystonia. J Neurol Neurosurg Psychiatry 1998;64:6-12.

140. Benecke R, Jost WH, Kanovsky P, et al. A new botulinum toxin type A free of complexing proteins for treatment of cervical dystonia. Neurology 2005;64:1949-1951.

141. Pappert EJ, Germanson T, Myobloc/Neurobloc European Cervical Dystonia Study G. Botulinum toxin type B vs. type A in toxin-naive patients with cervical dystonia: Randomized, double-blind, noninferiority trial. Mov Disord 2008;23:510-517.

142. Coubes P, Cif L, El Fertit H, et al. Electrical stimulation of the globus pallidus internus in patients with primary generalized dystonia: long-term results. J Neurosurg 2004;101:189-194.

143. Haridas A, Tagliati M, Osborn I, et al. Pallidal deep brain stimulation for primary dystonia in children. Neurosurgery 2011;68:738743; discussion 743.

144. Sarubbo S, Latini F, Quatrale R, et al. Five-year follow-up of 10 patients treated with globus pallidus internus deep brain stimulation for segmental or multisegmental dystonia. Stereotact Funct Neurosurg 2012;90:84-91. 